\title{
Modern management of paediatric obstructive salivary disorders: long-term clinical experience
}

\section{La gestione moderna dei disordini ostruttivi salivari in età pediatrica: esperienza clinica a lungo termine}

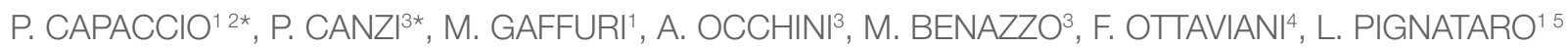

${ }^{1}$ Department of Otolaryngology and Head and Neck Surgery, Fondazione IRCCS Ca' Granda Ospedale Maggiore Policlinico, Milan, Italy; ${ }^{2}$ Department of Biomedical, Surgical and Dental Sciences, Università degli Studi di Milano, Milan, Italy; ${ }^{3}$ Department of Otorhinolaryngology, University of Pavia, IRCCS Policlinico San Matteo Foundation, Pavia, Italy; ${ }^{4}$ Department of Clinical Sciences and Community Health, Università degli Studi di Milano Ospedale Fatebenefratelli San Giuseppe, Milano; ${ }^{5}$ Department of Clinical Sciences and Community Health, Università degli Studi di Milano, Milan, Italy

${ }^{\star}$ These authors contributed equally to this article.

\section{SUMMARY}

Recent technological improvements in head and neck field have changed diagnostic and therapeutic strategies for salivary disorders. Diagnosis is now based on colour Doppler ultrasonography (US), magnetic resonance (MR) sialography and cone beam 3D computed tomography (CT), and extra- and intracorporeal lithotripsy, interventional sialendscopy and sialendoscopy-assisted surgery are used as minimally invasive, conservative procedures for functional preservation of the affected gland. We evaluated the results of our long-term experience in the management of paediatric obstructive salivary disorders. The study involved a consecutive series of 66 children ( 38 females) whose obstructive salivary symptoms caused by juvenile recurrent parotitis $(J R P)(n=32)$, stones $(n=20)$, ranula $(n=9)$ and ductal stenosis $(n=5) .45$ patients underwent interventional sialendoscopy for JRP, stones and stenoses, 12 a cycle of extracorporeal shockwave lithotripsy (ESWL), three sialendoscopy-assisted transoral surgery, one drainage, six marsupialisation, and two suturing of a ranula. Three children underwent combined ESWL and interventional sialendoscopy, and seven a secondary procedure. An overall successful result was obtained in $90.9 \%$ of cases. None of the patients underwent traditional invasive sialadenectomy notwithstanding persistence of mild obstructive symptoms in six patients. No major complications were observed. Using a diagnostic work-up based on colour Doppler US, MR sialography and cone beam 3D TC, children with obstructive salivary disorders can be effectively treated in a modern minimally-invasive manner by extracorporeal and intracorporeal lithotripsy, interventional sialendoscopy and sialendoscopy-assisted transoral surgery; this approach guarantees a successful result in most patients, thus avoiding the need for invasive sialadenectomy while functionally preserving the gland.

KEYWORDS: Salivary calculi $\bullet$ Ranula $\bullet J u v e n i l e r e c u r r e n t$ parotitis $\bullet$ Salivary ductstenosis $\bullet$ Paediatric age $\bullet$ Sialendoscopy $\bullet$ Ultrasonography $\bullet$ Extracorporeal lithotripsy • Intracorporeal lithotripsy • Sialendoscopy-assisted transoral surgery

\section{RIASSUNTO}

I disordini ostruttivi salivari sono infrequenti nell'età pediatrica. I recenti progressi tecnologici nel distretto della testa e del collo hanno modificato la strategia diagnostica e terapeutica dei disordini salivari. La diagnosi è oggi basata sull'eco color Doppler, sulla scialo-RMN, sulla cone beam 3D TC, mentre la litotrissia extracorporea ed intracorporea, la scialoendoscopia interventistica, la chirurgia scialoendoscopico-assistita, sono attualmente utilizzati come procedure conservative e mininvasive per la preservazione funzionale della ghiandola affetta. Abbiamo analizzato i risultati dell'esperienza clinica a lungo termine nel trattamento dei disordini ostruttivi dell'età pediatrica. Un gruppo consecutivo di 66 pazienti pediatrici (38 femmine) con sintomi salivari ostruttivi causati da parotite ricorrente pediatrica ( 32 pazienti), calcoli (20), stenosi duttali (5), e ranule (9) è stato incluso nello studio. 45 pazienti sono stati sottoposti a scialoendoscopia interventistica per parotite ricorrente, calcoli e stenosi, 12 pazienti sono stati sottoposti ad un ciclo di litotrissia extracorporea (ESWL), tre pazienti a chirurgia transorale scialoendoscopico-assistita, un paziente a drenaggio, sei a marsupializzazione e due a sutura della ranula. $\mathrm{Nel}$ 90,9\% è stato raggiunto un risultato favorevole. L'approccio combinato di litotrissia salivare extracorporea e di scialoendoscopia interventistica è stato utilizzato in tre pazienti ed una procedura secondaria è stata eseguita in sette pazienti. Nessun paziente è stato sottoposto a scialoadenectomia nonostante la persistenza di modesti sintomi ostruttivi in sei pazienti. Non è stata osservata alcuna complicanza maggiore. Adottando un adeguato iter diagnostico mediante eco color Doppler delle ghiandole salivari, scialo-RMN e cone beam 3D TC, $i$ pazienti pediatrici con disordini ostruttivi salivari possono essere efficacemente trattati con un approccio moderno mini-invasivo mediante tecniche di litotrissia extracorporea ed intracorporea, scialoendoscopia interventistica, e chirurgia transorale scialoendoscopico-assistita; questo approccio garantisce un risultato favorevole nella maggior parte dei pazienti evitando così il ricorso alla scialoadenectomia invasiva e mantenendo così la preservazione funzionale della ghiandola coinvolta.

PAROLE CHIAVE: Calcoli salivari $\bullet$ Ranula $\bullet$ Parotite ricorrente pediatrica $\bullet$ Stenosi duttale $\bullet$ Litotrissia salivare extracorporea $\bullet$ Litotrissia intracorporea $\bullet$ Ecografia $\bullet$ Chirurgia transorale 


\section{Introduction}

Salivary gland disorders other than infectious conditions are less frequent in children than in adults, and neoplastic lesions are rare. The most frequent clinical manifestations are inflammatory events, which occur in about $10 \%$ of all salivary gland disorders ${ }^{12}$. The wide range of factors involved in paediatric salivary gland disorders makes clinical management of childhood and adolescent salivary gland swelling challenging. Over the last 20 years or so, healthcare technological research has opened up new diagnostic and therapeutic perspectives. Recent radiological approaches have replaced conventional sialography for morphological investigation of the salivary gland duct system, and introduced more precise and non-invasive alternatives. The use of modern colour Doppler ultrasonography (US) allows a detailed assessment of salivary vascular anatomy and flow velocity ${ }^{2}$. Magnetic resonance (MR) sialography is a non-ionising, non-allergenic means of exploring salivary gland ducts that uses a natural contrast medium (saliva) and does not require duct cannulation ${ }^{3}$, and cone beam computed tomography (CBCT) has been proposed as a cheaper alternative to traditional CT that reduces the amount of radiation exposure, especially in paediatric patients ${ }^{4}$. First described in the 1990s, sialendoscopy ${ }^{56}$ is increasingly used because the advantage of seeing inside the duct system allows both diagnostic and therapeutic procedures. Historical treatments such as partial or complete gland removal are being progressively abandoned in favour of minimally invasive approaches, which currently represent the new medical standard of care and have a considerable impact on paediatric patients. Nevertheless, there is still a relative paucity of published data concerning recurrent inflammatory disorders of the salivary glands in children ${ }^{789}{ }^{10-13}$, and so the aim of this study was to analyse our 20-year experience of paediatric salivary obstructive disorders and their minimally invasive management.

\section{Materials and methods}

Between March 1994 and December 2015, 66 children with obstructive salivary gland or oral floor swelling (38 girls; mean age 7.9 years, range 1-16) were treated at the Departments of Otolaryngology and Head and Neck Surgery of Fondazione IRCCS Ca' Granda Policlinico of Milan and Fondazione IRCCS Policlinico San Matteo of Pavia. All patients had experienced at least one episode of parotid, submandibular or sublingual swelling. All patients underwent a complete ENT clinical examination, including inspection and palpation of the oral floor and major salivary glands, and high-resolution US and Doppler US assessments (Hitachi H21, 7.5 MHz, Hitachi High Technology Corporation Ltd., Tokyo, Japan) (Fig.1a); further investigations included MR sialography and CBCT (Fig. 1b) when necessary. Subsequently, various therapeutic options were adopted on the basis the clinical and radiological findings.

\section{Therapeutic options}

\section{Diagnostic and interventional sialendoscopy}

Sialendoscopy was performed under general anaesthesia with the patients in a half-seated position, with the head on a headrest turned towards the surgeon and mouth held open by a small gag. Endoscopic exploration of the ductal system of the affected gland was performed using semi-rigid salivary sialendoscopes (Fig. 2a) with outer diameters of 0.8-1.1 mm (Nahlieli and Erlangen sialendoscopes, Karl Storz ${ }^{\circledR}$, Tuttlingen, Germany). Insertion through the salivary duct was preceded by appropriate dilation with standard salivary probes and conical dilators (Bowman probes 0000-6, Karl Storz ${ }^{\circledR}$, Tuttlingen, Germany) and, when necessary, minimal papillotomy or limited minimal sialodochotomy. A sialendoscopic diagnosis of lithiasis was made by directly visualising the duct stone, and a diagnosis of duct stenosis was based on the grading system of Koch et

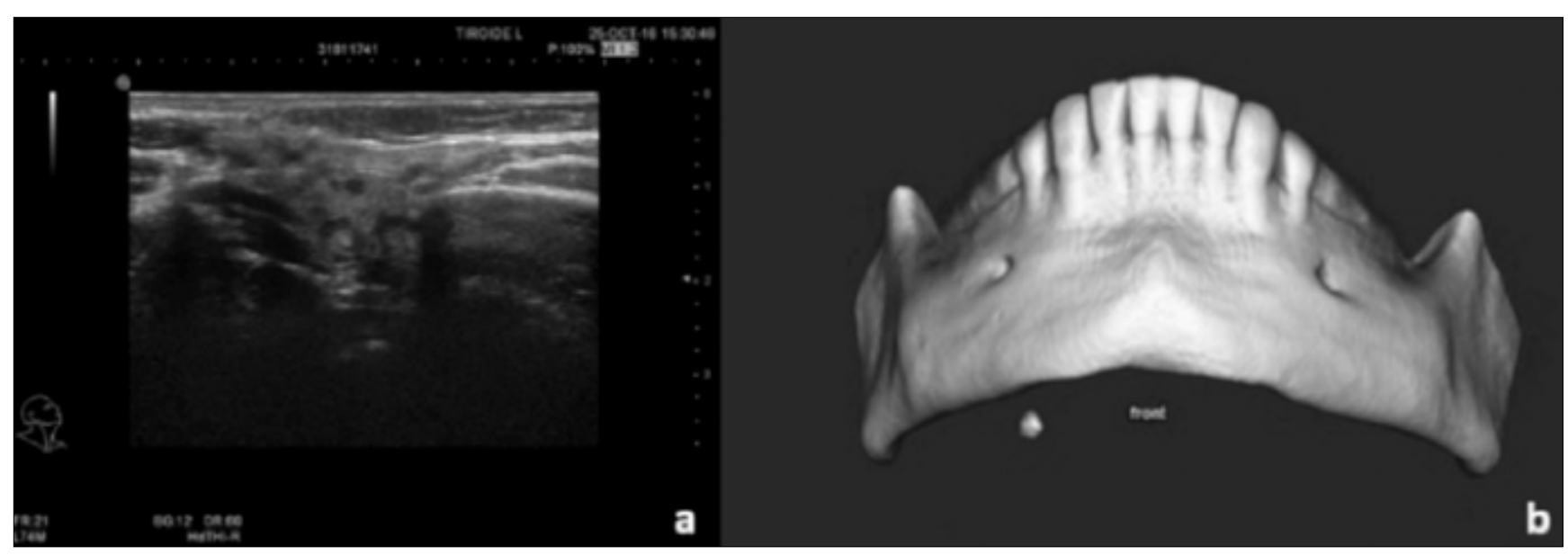

Fig. 1. High-resolution US of a patient affected by JRP, showing typical hypoechoic areas and heterogeneous echoes (a); 3D-CBCT image showing a right submandibular stone in a 15-year-old boy. 


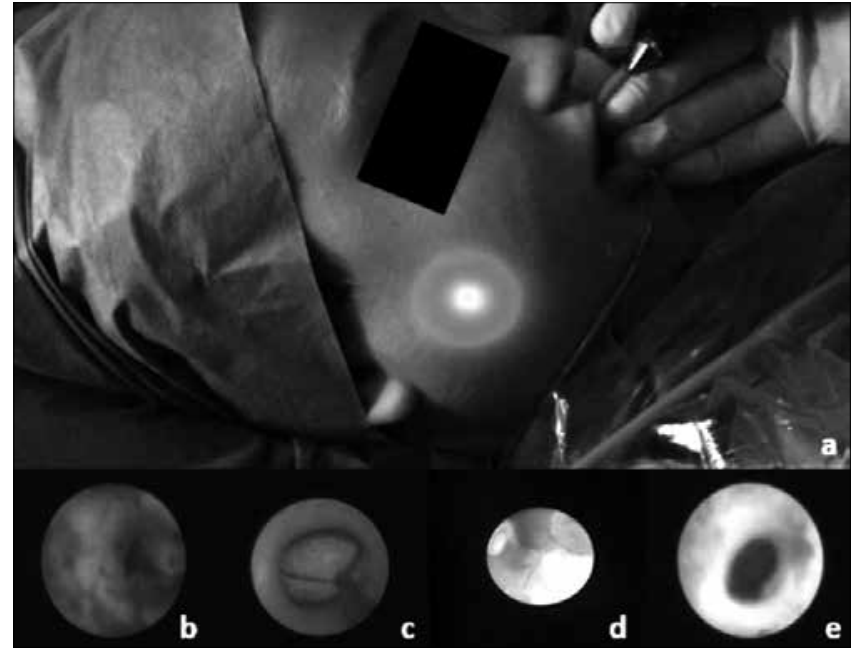

Fig. 2. Endoscopic exploration of the ductal system of a right parotid gland by means of a semi-rigid sialendoscope (a); sialodochitis of the Stensen's duct (b); a stone trapped in a basket wire (c); intraductal fragmentation of a stone by means of holmium:YAG laser lithotripter (the red light of the laser is visible at the centre of the picture) (d); endoscopic image of a salivary duct stenosis (e).

al. ${ }^{14}$. Additional sialendoscopic findings were represented by sialodochitis (Fig. 2b), mucous plugs and other duct anomalies. When necessary, interventional sialendoscopy was performed during the same procedure. Parotid or submandibular stones of $<3 \mathrm{~mm}$ were extracted using customised wire baskets (Fig. 2c) (Karl Storz ${ }^{\circledR}$, Tuttlingen, Germany; NCircle, Cook Medical Inc ${ }^{\circledR}$, Bloomington, IN, USA; Boston Scientific ${ }^{\circledR}$, Marlborough, MA, USA), forceps (Karl Storz $^{\circledR}$, Tuttlingen, Germany), balloons (Karl Storz ${ }^{\circledR}$, Tuttlingen, Germany), or a manual drill (Karl Storz ${ }^{\circledR}$, Tuttlingen, Germany). An intraductal holmium:YAG laser lithotripter (Lumenis ${ }^{\circledR}$, Dreieich, Germany) carried by a semi-flexible fibre (diameter 200 or $365 \mu \mathrm{m}$, with a power of 2.5-3.5 W, a rate of $5 \mathrm{~Hz} / \mathrm{sec}$, and energy of 0.5-0.7 J) was used to fragment stones of $\geq 3 \mathrm{~mm}$ in diameter before extraction (Fig. 2d). Duct stenoses (Fig. 2e) were dilated by simple irrigation, balloon dilation and/or endoscopic stent positioning (venous catheter, Venflon, Artsana, Grandate, Italy; salivary polymeric stent, Optimed ${ }^{\circledR}$, Ettlingen, Germany). At the end of the procedure the duct was washed with $2 \mathrm{~mL}$ of a betamethasone solution, corresponding to two vials of $4 \mathrm{mg} / 1 \mathrm{~mL}$ each. All patients received one-shot antibiotic therapy (amoxicillin and clavulanic acid) during the surgical procedure.

\section{Extracorporeal shockwave lithotripsy (ESWL)}

Children with single or multiple parotid or submandibular calculi with a main diameter of 3-7 mm underwent a cycle of electromagnetic ESWL. A dedicated lithotripter with a mobile arm (Minilith SL -1, Storz Medical, Kreutzlingen, Switzerland) was used for treatment of salivary calculi. With the patient seated on a dentist's chair in a supine semi-reclined position, the ultrasound-guided shockwave generated by a small-diameter, cylindric, electromagnetic source was focused on the salivary stone using a parabolic reflector within the cushion. The $2.4 \mathrm{~mm}$ size of the shockwave focus allows the treatment of stones with diameters of $\geq 2.4 \mathrm{~mm}$. The pulse frequency of the wave may vary from 0.5 to $2 \mathrm{~Hz}$, and no more than 4000 shockwaves may be administered per session. Continuous sonographic monitoring allows direct visualisation of the degree of fragmentation during treatment, and avoids lesions to the surrounding tissues. A typical session of ESWL for sialolithiasis lasts approximately $30 \mathrm{~min}$ (median duration $29 \mathrm{~min}$; range $20-37 \mathrm{~min}$ ), and the treatment is repeated weekly.

Sialendoscopy-assisted transoral surgery for discrete and large submandibular stones of the main duct and hiloparenchymal region

Single or multiple palpable stones in the main duct and hiloparenchymal submandibular region were sometimes removed using a sialendoscopy-assisted oral procedure with headlight illumination and the patient under general anaesthesia. The mouth was held open by a small gag, the tongue was retracted and the oral floor was infiltrated with $5 \mathrm{~mL}$ of mepivacaine $25 \mathrm{mg} / \mathrm{ml}+$ adrenaline $5 \mu \mathrm{g} /$ ml. After dilating the duct with lacrimal probes (Fig. 3), a semi-rigid sialendoscope was inserted into the ductal system to localise the stone. A retropapillar incision was made over the oral floor mucosa, the tissue was bluntly dissected using sharp-tipped scissors and the duct was isolated from the surrounding tissues up to the second molar (the safe zone above the lingual nerve). The lingual nerve was identified running obliquely from the tongue, beneath the duct to the submandibular ganglion laterally, and then ascending medially over the submandibular duct as this enters the gland. The submandibular gland was identified by means of external digital pressure from the submandibular region. The duct was stretched using a fine haemostat swab and a minimal incision of the duct or the hiloparenchymal area was made over the stone, which was subsequently removed by means of a dedicated Freer elevator (Martin, Tuttlingen, Germany). The duct was then irrigated with normal saline to clean the hilar region and remove stone debris and, when possible, the ductal system was explored endoscopically to check for residual stones. In order to avoid the risk of post-operative duct stenosis a 14-20 G Venflon tube (Artsana, Grandate, Italy) was usually positioned through the papilla to stent the duct, and secured to the oral floor mucosa by means of a resorbable suture. Finally, the incision was closed using fine resorbable sutures (6.0 Vicryl) after positioning a fibrillar haemostatic net (Tabotamp, Johnson \& Johnson Medical Limited, Gargrave, Skipton, UK) in order to avoid the risk of stricture or stenosis. The oral floor was then sutured using resorbable stitches (3.0 Vicryl). 


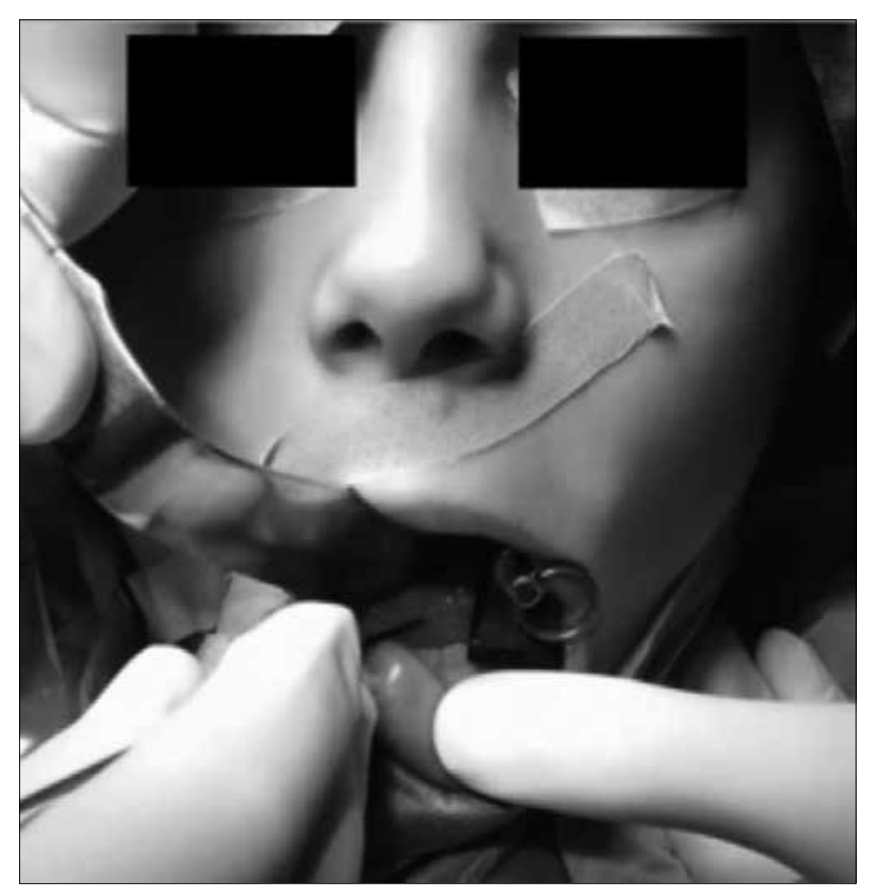

Fig. 3. To perform a sialendoscopy-assisted oral procedure, the mouth is held open by a small gag and the tongue retracted; the first surgical step is to dilate the duct with lacrimal probes.

\section{Oral surgery for sublingual ranulas}

Oral floor ranulas (Fig. 4a) were treated by various surgical procedures, mainly consisting of drainage, marsupialisation and suturing.

\section{Drainage}

With the patient under local anaesthesia, saliva was aspirated using a wide-bore needle to completely decompress the ranula, or the oral floor was incised using a size 11 scalpel.

\section{Traditional and modified marsupialisation}

Marsupialisation involved excising the ranula roof and suturing the lesion edges to the oral mucosa to maintain

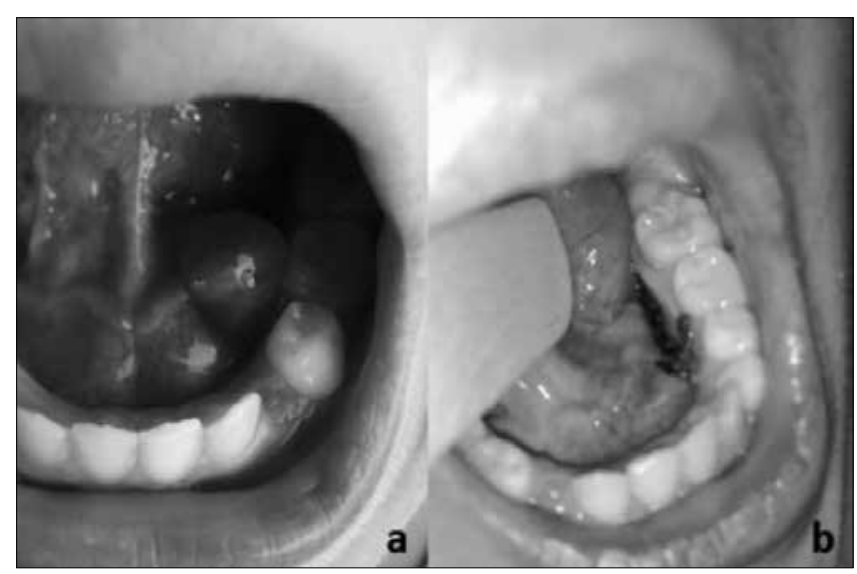

Fig. 4. a left oral floor ranula in a female child (a); sutures in place 1 month after surgery, with no recurrence detectable (b). communication with the oral cavity; in the case of modified marsupialisation, suturing the ranula edges to the oral mucosa preceded the excision of the roof of the lesion ${ }^{15}$. To avoid the resealing of the edge of the wound and subsequent recurrence, modified nasal packing (Merocel) was left over the floor of the lesion and sutured to the oral mucosa for three days.

\section{Suturing}

This technique has recently been described by Goodson et al. ${ }^{16}$. Two or three interrupted 3-0 gauge silk sutures are placed through the edge of the sublingual gland around the origin of the ranula. The leaking salivary unit is caught within the sutures and strangulated. The sutures help to decompress the ranula and cause fibrosis and scarring of the sublingual gland at the site of the salivary leak. To improve the process of scarring and fibrosis, we modified McGurk's technique by using two additional silk sutures placed positioned perpendicularly to the others ì to create loose rings that favour saliva leakage from the pseudocyst, prevent puffiness of the cavity and aid the scarring process (Fig. 4b). The sutures do not always need to be removed as they often come away during the healing process.

\section{Post-operative follow-up}

All patients received antibiotic prophylaxis (combined amoxicillin sodium and clavulanic acid $50 \mathrm{mg} / \mathrm{kg} /$ day for seven days) and, when necessary, steroids (betamethasone $0.2 \mathrm{mg} / \mathrm{kg} /$ day) to reduce oedema of the mouth floor. The children who underwent oral surgery for stones or ranulas followed a cold semi-solid diet for the first week. All patients were clinically followed up after one week, and then minimally after one, six and 12 months. Therapeutic success was considered complete when the cause of the obstruction was completely removed or the patient was free of symptoms, and partial when the cause of the obstruction was not completely removed (e.g. residual stones of $<2 \mathrm{~mm}$ ) or when the number of episodes of sialadenitis was reduced. The procedure was considered unsuccessful when the cause of obstruction was not removed or there was no change in the symptom-related condition of the patient. In the case of recurrent symptoms, a US evaluation was made six months after the procedure.

\section{Results}

Of the 66 patients analysed, $32(48.5 \%)$ suffered from juvenile recurrent parotitis (JRP), 25 (37.9\%) from recurrent obstructive sialadenitis and nine (13.6\%) from oral floor ranulas (Table I). Baseline data and detailed outcomes are summarised in Tables II-V. The minimally invasive management of paediatric obstructive sialadenitis had a complete therapeutic effect on $90.9 \%$ of the glands. No temporary or persistent untoward effect was observed. None of the patients underwent invasive pa- 
Table I. Paediatric recurrent sialadenitis, case series (1994-2015).

\begin{tabular}{lc} 
Pathology & Number of patients \\
\hline JRP & 32 \\
Oral floor ranula & 9 \\
Parotid obstructive sialadenitis & 9 \\
Submandibular obstructive sialadenitis & 16 \\
Total & $\mathbf{6 6}$ \\
\hline
\end{tabular}

Table II. JRP series.

\begin{tabular}{lc} 
Number of patients & $\mathbf{n}$ \\
Male & 32 \\
Female & 13 \\
Age (years) & 19 \\
Mean & \\
Median & 7.2 \\
Range & 6 \\
Side & 1 to 16 \\
Right & \\
Left & 13 \\
Bilateral & 9 \\
No. of recurrences/year before sialendoscopy & 10 \\
Mean & \\
Median & 4.6 \\
Range & 4 \\
No. of sialendoscopies & 2 to 10 \\
Follow-up (months) & 42 \\
Mean & \\
Range & 23 \\
No. of patients with recurrences after sialendoscopy & 7 \\
Secondary SE procedures & 35 \\
Medical therapies & 3 \\
\hline
\end{tabular}

rotid or submandibular sialadenectomy. The results of each group of obstructive salivary gland disorders are discussed below.

\section{Juvenile recurrent parotitis (JRP) (Table II)}

Thirty-two patients with JRP were enrolled, making JRP the main cause of recurrent sialadenitis in our series. The patients were predominantly female $(59.4 \%)$ and had a mean age of 7.2 years at the time of presentation. Approximately one-third (10/32) complained of bilateral involvement and recurrent parotitis before sialendoscopy occurred up to 10 times per year (mean 4.6 times). Diagnosis of JRP was based on clinical and imaging findings. In all cases, US scans detected typical multiple hypoechoic areas corresponding to duct dilation, and identified hyperplasic cells around the ducts. Colour Doppler US showed reactive intraparenchymal lymph nodes and gland hyper or hypo-vascularisation depending on whether JRP was in an acute or quiescent phase.

Forty-two sialendoscopies were carried out under general anaesthesia, 10 of which were performed bilaterally during the same procedure. The secondary salivary ducts were explored in all cases, and third order branching was investigated in $40 \%$ of procedures. The most frequent endoscopic finding was a white wall appearance; main duct strictures (Koch's type I) and dilation were identified in all of the glands, and mucous plugs in $60 \%$ of the ducts. Interventional sialendoscopy involved irrigating the ductal system with saline solution and steroids.

At the time of follow-up, 25 patients were free from symptoms with no episodes of recurrence, and seven patients experienced symptom recurrence, three of whom underwent secondary sialendoscopies with positive therapeutic effects and one was cured with medical therapy.

\section{Paediatric oral floor ranula (Table III)}

Six female and three male children had simple oral floor ranulas with a mean size of $1.3 \mathrm{~cm}$; the right side was most frequently involved. The minimally invasive surgi-

Table III. Paediatric oral floor ranulas.

\begin{tabular}{|c|c|}
\hline & $\mathrm{n}$ \\
\hline Number of patients & 9 \\
\hline Male & 3 \\
\hline Female & 6 \\
\hline \multicolumn{2}{|l|}{ Age (years) } \\
\hline Mean & 6.9 \\
\hline Range & 5 to 13 \\
\hline \multicolumn{2}{|l|}{ Side } \\
\hline Right & 7 \\
\hline Left & 2 \\
\hline Bilateral & 0 \\
\hline \multicolumn{2}{|l|}{ Size (cm) } \\
\hline Mean & 1.3 \\
\hline Range & 0.8 to 2 \\
\hline \multicolumn{2}{|l|}{ Treatment } \\
\hline Drainage & 1 \\
\hline Marsupialisation & 6 \\
\hline Suture & 2 \\
\hline \multicolumn{2}{|l|}{ Follow-up (months) } \\
\hline Mean & 11 \\
\hline Range & 4 to 16 \\
\hline No. of recurrences after 1 st treatment & 2 \\
\hline Secondary procedures & 2 \\
\hline Patients still symptomatic after 2nd treatment & 1 \\
\hline
\end{tabular}


cal treatments used were marsupialisation (six patients), suturing (two patients) and drainage (one patient). An immediate recurrence was observed in two of the six patients who underwent drainage followed by traditional and modified marsupialisation $(2 / 6 ; 33 \%)$; there were no recurrences in patients who underwent the suturing technique. A secondary procedure was performed in recurred patients; one patient is still symptomatic.

\section{Recurrent obstructive sialadenitis (Tables IV-V)}

The 25 treated patients showed a significant prevalence of submandibular over parotid involvement (64\% vs 36\%). There were no substantial differences in gender or side. Mean age at the time of enrolment was 8.9 years, and the symptoms had lasted for more than six months. Sialolithiasis was the most frequent cause of obstruction (20/25, $80 \%)$ of both parotid (7/9) and submandibular glands (13/16), and the mean stone size was $4.5 \mathrm{~mm}$.

ESWL was the primary treatment in $60 \%$ of cases $(12 / 20)$ : the stone-free rate after extracorporeal lithotripsy was $75 \%$ (9/12), and combined sialendoscopic stone removal was required in $25 \%$ of cases (3/12) because of residual symptomatic stone fragments. Thirteen interventional sialendoscopies were carried out, being the primary treatment in the case of eight duct stones and five duct stenoses. Among the patients with duct anomalies, one was a newborn infant with bilateral atresia of the papilla, which was treated by surgically incising the final tract of the submandibular duct followed by a sialendoscopic exploration of the duct system. Laser lithotripsy was performed in one eight yearsold patient with a $2 \mathrm{~mm}$ stone located in a secondary intraparenchymal branch of the duct system. Treatment failures (i.e. persistent salivary symptoms) were observed in two patients, one with a submandibular duct stenosis and the other with a parenchymal parotid stone.

\section{Discussion}

Twentieth century medical science has led to major advances in our knowledge of pathophysiology and the minimally invasive management of diseases. In the case of salivary gland disorders, modern approaches have proved to be effective in adults ${ }^{317-19}$, but there is relatively little published information concerning children ${ }^{7-13}$. We herein describe our 20-year experience of treating 66 paediatric patients with recurrent salivary obstructive disorders; to the best of our knowledge, this is the largest series of paediatric patients described in this field. All patients were treated using minimally invasive strategies, which were successful in $90.9 \%$ of cases; none of the patients required salivary gland removal. In all cases, we were able to enter the duct system using the latest generation of miniaturised sialendoscopes, and no adverse events were encountered.

In line with previous reports ${ }^{20}$, the most common cause of recurrent paediatric sialadenitis in our experience was JRP.
Table IV. Paediatric parotid obstructive sialadenitis

\begin{tabular}{|c|c|}
\hline & $\mathrm{n}$ \\
\hline Number of patients & 9 \\
\hline Male & 5 \\
\hline Female & 4 \\
\hline \multicolumn{2}{|l|}{ Age (years) } \\
\hline Mean & 9.2 \\
\hline Range & 5 to 13 \\
\hline \multicolumn{2}{|l|}{ Side } \\
\hline Right & 6 \\
\hline Left & 3 \\
\hline Bilateral & 0 \\
\hline \multicolumn{2}{|l|}{ Pathology } \\
\hline Sialolithiasis & 7 \\
\hline \multicolumn{2}{|l|}{ Size of the stone (mm) } \\
\hline Mean & 4.97 \\
\hline Range & 2 to 7 \\
\hline Duct stenosis & 2 \\
\hline \multicolumn{2}{|l|}{ Type* } \\
\hline । & 2 \\
\hline$\|$ & 0 \\
\hline III & 0 \\
\hline \multicolumn{2}{|l|}{ Duration of symptoms (months) } \\
\hline Mean & 8.2 \\
\hline Range & 1 to 30 \\
\hline \multicolumn{2}{|l|}{ Primary Treatment } \\
\hline ESWL & 5 \\
\hline Interventional sialendoscopy & 4 \\
\hline \multicolumn{2}{|l|}{ Results of ESWL } \\
\hline No. of patients stone free after ESWL & 3 \\
\hline Residual fragments $<2$ mm & 2 \\
\hline Symptomatic & 2 \\
\hline Asymptomatic & 0 \\
\hline \multicolumn{2}{|l|}{ Results of sialendoscopy } \\
\hline No. of patients stone free after sialendoscopy & 1 \\
\hline Residual stones & 1 \\
\hline Recurrent duct stenosis & 0 \\
\hline \multicolumn{2}{|l|}{ Follow-up (months) } \\
\hline Mean & 12 \\
\hline Range & 6 to 14 \\
\hline \multicolumn{2}{|l|}{ Further treatments } \\
\hline Interventional sialendoscopy following ESWL & 2 \\
\hline Residual stones after 2nd sialendoscopy & 0 \\
\hline ESWL following failure sialendoscopy & 1 \\
\hline
\end{tabular}

${ }^{*}$ Classification of duct stenosis according to Koch et al. ${ }^{14}$

Some studies have suggested that the pathophysiology of JRP is immune-mediated ${ }^{21}{ }^{22}$, and our colour Doppler US findings of reactive lymphatic tissue in all 42 glands seem to support this hypothesis, which is further supported by the therapeutic effect of steroid injections during operative sialendoscopy ${ }^{212}$. In line with previous reports ${ }^{23-25}$, sialen- 
Table V. Paediatric submandibular obstructive sialadenitis

\begin{tabular}{|c|c|}
\hline & $\mathrm{n}$ \\
\hline Number of patients & 16 \\
\hline Male & 7 \\
\hline Female & 9 \\
\hline \multicolumn{2}{|l|}{ Age (years) } \\
\hline Mean & 8.6 \\
\hline Range & 5 to 15 \\
\hline \multicolumn{2}{|l|}{ Side } \\
\hline Right & 7 \\
\hline Left & 9 \\
\hline Bilateral & 0 \\
\hline \multicolumn{2}{|l|}{ Pathology } \\
\hline Sialolithiasis & 13 \\
\hline \multicolumn{2}{|l|}{ Size of the stone $(\mathrm{mm})$} \\
\hline Mean & 4.1 \\
\hline Range & 1 to 7 \\
\hline Duct stenosis & 3 \\
\hline \multicolumn{2}{|l|}{ Type $\left(^{*}\right)$} \\
\hline I & 2 \\
\hline$\|$ & 1 \\
\hline III & 0 \\
\hline \multicolumn{2}{|l|}{ Duration of symptoms (months) } \\
\hline Mean & 6.5 \\
\hline Range & 1 to 13 \\
\hline \multicolumn{2}{|l|}{ Primary Treatment } \\
\hline ESWL & 7 \\
\hline Sialendoscopy-assisted procedures & 9 \\
\hline Interventional SE & 6 \\
\hline SE Endoral procedures & 2 \\
\hline SE Transoral procedures & 1 \\
\hline \multicolumn{2}{|l|}{ Results of ESWL } \\
\hline No. of patients stone free after ESWL & 5 \\
\hline Residual fragments $<2 \mathrm{~mm}$ & 2 \\
\hline Symptomatic & 1 \\
\hline Asymptomatic & 1 \\
\hline \multicolumn{2}{|l|}{ Results of sialendoscopic-assisted surgery } \\
\hline No. of patients stone free after sialendoscopy & 5 \\
\hline Residual stones & 0 \\
\hline Recurrent duct stenosis & 1 \\
\hline \multicolumn{2}{|l|}{ Follow-up (months) } \\
\hline Mean & 11 \\
\hline Range & 6 to 15 \\
\hline \multicolumn{2}{|l|}{ Further treatments } \\
\hline Interventional sialendoscopy following ESWL & 1 \\
\hline Residual stones after 2nd sialendoscopy & 0 \\
\hline ESWL following failure sialendoscopy & \\
\hline
\end{tabular}

doscopy proved to be remarkably beneficial as it reduced the mean frequency of JRP attacks from 4.6 to 0.5 per year, thus giving patients a better quality of life until puberty.
Childhood sialolithiasis is quite rare, accounting for about $3-5 \%$ of all salivary stones ${ }^{726}$. In our 20 cases, the modern methods of ESWL and sialendoscopy alone or combined with a transoral surgical approach led to complete clinical control in $95 \%$ of patients, although the combination of two techniques (ESWL and sialendoscopy) and the repetition of a transoral removal of a parenchymal stone was necessary in four cases. Stone lithotripsy was required to treat $65 \%$ of stones (13/20): 12 patients underwent ESWL and one patient sialendoscopy-assisted laser lithotripsy. ESWL was mainly used during the first 10 years of our experience ${ }^{27}$, but the advent of sialendoscopy in 2001 allowed us to treat some patients with residual stone fragments after lithotripsy. Current technology is evolving towards intracorporeal laser or pneumatic fibre lithotripsy techniques, but only a few studies of intraductal laser and pneumatic lithotripsy have been published ${ }^{72829}$ and no final conclusion can be drawn, especially in the case of children.

The optimal management of oral floor ranula is still controversial ${ }^{30-35}$, and our experience reflects the evolution of various approaches. Traditional treatments include sclerotherapy, the removal of the cystic wall between the ranula and the sublingual gland, and drainage and marsupialisation of the ranula ${ }^{30-35}$. None of our patients underwent salivary gland and ranula excision but, as expected, ranula drainage was followed by immediate recurrence, and the rate of recurrence was $33 \%$ after marsupialisation; modified marsupialisation with cavity packing and the suture technique seemed to work better. The low rate of recurrence justifies the use of a minimally invasive alternative to invasive sublingual sialadenectomy in this population $^{30-35}$.

\section{Conclusions}

Paediatric obstructive salivary disorders are not common and their treatment is made challenging by a number of factors: the patients' age, the large number of causes, and the limited data available in the literature. However, recent developments in our understanding of the pathophysiological mechanisms of salivary gland disorders have positively influenced the progress of minimally invasive treatments. In our experience, a modern diagnostic and therapeutic approach using extracorporeal and intracorporeal lithotripsy, interventional sialendoscopy and sialendoscopy-assisted transoral surgery was successful in most cases, thus avoiding the need for invasive sialadenectomy. Future innovations in minimally invasive technologies will guarantee the functional preservation of the affected gland in all paediatric patients.

\section{References}

1 Jabbour N, Tibesar R, Lander T, et al. Sialendoscopy in children. Int J Pediatr Otorhinolaryngol 2010;74:347-50. 
2 Iro H, Zenk J. Salivary gland diseases in children. GMS Curr Top Otorhinolaryngol Head Neck Surg 2014;1;13:Doc06.

3 Capaccio P, Torretta S, Ottaviani F, et al. Modern management of obstructive salivary diseases. Acta Otorhinolaryngol Ital 2007;27:161-72.

4 Kroll B, May A, Wittekindt C, et al. Cone beam computed tomography (CBCT) sialography: an adjunct to salivary gland ultrasonography in the evaluation of recurrent salivary gland swelling. Oral Surg Oral Med Oral Pathol Oral Radiol 2015;120:771-5.

5 Katz P. New method of examination of the salivary glands: the fiberscope. Inf Dent 1990;72:785-6.

6 Königsberger R, Feyh J, Goetz A, et al. Endoscopically controlled laser lithotripsy in the treatment of sialolithiasis. Laryngorhinootologie 1990;69:322-3.

7 Faure F, Querin S, Dulguerov P, et al. Pediatric salivary gland obstructive swelling: sialendoscopic approach. Laryngoscope 2007;117:1364-7.

8 Martins-Carvalho C, Plouin-Gaudon I, Quenin S, et al. Pediatric sialendoscopy: a 5-year experience at a single institution. Arch Otolaryngol Head Neck Surg 2010;136:33-6.

9 Haberal I, Gocmen H, Samim E. Surgical management of pediatric ranula. Int J Pediatr Otorhinolaryngol 2004;68:161-3.

$10 \mathrm{Su} \mathrm{CH}$, Lee KS, Hsu JH, et al. Pediatric sialendoscopy in Asians: A preliminary report. J Pediatr Surg 2016;51:1684-7.

11 Semensohn R, Spektor Z, Kay DJ, et al. Pediatric sialendoscopy: initial experience in a pediatric otolaryngology group practice. Laryngoscope 2015;125:480-4.

12 Hackett AM, Baranano CF, Reed M, et al. Sialoendoscopy for the treatment of pediatric salivary gland disorders. Arch Otolaryngol Head Neck Surg 2012;138:912-5.

13 Jabbour N, Tibesar R, Lander T, et al. Sialendoscopy in children. Int J Pediatr Otorhinolaryngol 2010;74:347-50.

14 Koch M, Iro H, Zenk J. Sialendoscopy-based diagnosis and classification of parotid duct stenoses. Laryngoscope 2009;119:1696-703

15 Zhi K, Gao L, Ren W. What is new in management of pediatric ranula? Curr Opin Otolaryngol Head Neck Surg 2014;22:525-9.

16 Goodson AM, Payne KF, George K, et al. Minimally invasive treatment of oral ranulae: adaption to an old technique. $\mathrm{Br} \mathrm{J}$ Oral Maxillofac Surg 2015;53:332-5.

17 Strychowsky JE, Sommer DD, Gupta MK, et al. Sialendoscopy for the management of obstructive salivary gland disease: a systematic review and meta-analysis. Arch Otolaryngol Head Neck Surg 2012;138:541-7.

18 Gallo A, Benazzo M, Capaccio P et al. Sialoendoscopy: state of the art, challenges and further perspectives. Round Table, $101^{\text {st }}$ SIO National Congress, Catania 2014. Acta Otorhinolaryngol Ital 2015;35:217-33.

19 Capaccio P, Torretta S, Pignataro L. The role of adenectomy for salivary gland obstructions in the era of sialendoscopy and lithotripsy. Otolaryngol Clin North Am 2009;42:1161-71.

20 Francis CL, Larsen CG. Pediatric sialadenitis. Otolaryngol Clin North Am 2014;47:763-78.

21 Ussmuller J, Donath K. Clinical, histopathologic and immunohistochemical studies of chronic sialectatic parotitis in childhood and adolescence. Klin Padiatr 1999;211:165-71.

${ }^{22}$ Shkalim V, Monselise Y, Mosseri R, et al. Recurrent parotitis in selective IgA deficiency. Pediatr Allergy Immunol 2004;15:281-3.

23 Canzi P, Occhini A, Pagella F, et al. Sialendoscopy in juvenile recurrent parotitis: a review of the literature. Acta Otorhinolaryngol Ital 2013;33:367-73

24 Ramakrishna J, Strychowsky J, Gupta M, et al. Sialendoscopy for the management of juvenile recurrent parotitis: a systematic review and meta-analysis. Laryngoscope 2015;125:1472-9.

25 Capaccio P, Sigismund PE, Luca N, et al. Modern management of juvenile recurrent parotitis. J Laryngol Otol 2012;126:1254-60.

26 Ogden MA, Rosbe KW, Chang JL. Pediatric sialendoscopy indications and outcomes. Curr Opin Otolaryngol Head Neck Surg 2016;24:529-35.

27 Ottaviani F, Marchisio P, Arisi E, et al. Extracorporeal shockwave lithotripsy for salivary calculi in pediatric patients. Acta Otolaryngol. 2001;121:873-6.

28 Sionis S, Caria RA, Trucas M, et al. Sialoendoscopy with and without holmium:YAG laser-assisted lithotripsy in the management of obstructive sialadenitis of major salivary glands. Br J Oral Maxillofac Surg 2014;52:58-62.

29 Koch M, Mantsopoulos K, Schapher M, et al. Intraductal pneumatic lithotripsy for salivary stones with the StoneBreaker: preliminary experience. Laryngoscope 2016;126:1545-50.

30 Harrison JD. Modern management and pathophysiology of ranula: literature review. Head Neck 2010;32:1310-20.

31 Patel MR, Deal AM, Shockley WW. Oral and plunging ranulas: What is the most effective treatment? Laryngoscope 2009; 119:1501-9.

32 Sandrini FA, Sant'ana-Filho M, Rados PV. Ranula management: suggested modifications in the micro-marsupialization technique. J Oral Maxillofac Surg 2007;65:1436-8.

33 Mortellaro C, Dall'Oca S, Lucchina AG, et al. Sublingual ranula: a closer look to its surgical management. J Craniofac Surg 2008;19:286-90.

34 Hills A, Holden A, McGurk M. Evolution of the management of ranulas: change in a single surgeon's practice 2001-14. Br J Oral Maxillofac Surg 2016;54:992-96.

35 Sigismund PE, Bozzato A, Schumann M, et al. Management of ranula: 9 years' clinical experience in pediatric and adult patients. J Oral Maxillofac Surg 2013;71:538-44.

Address for correspondence: Pietro Canzi, Department of Otorhinolaryngology, IRCCS Policlinico San Matteo Foundation and University of Pavia, viale Camillo Golgi, 19, 27100, Pavia, Italy. Fax +39 0382528184.E-mail: pietro.canzi@unipv.it 